\title{
PSYCHOLOGICAL APPROACH TO THE CHARACTERS OF E LITERATURE FINAL FANTASY TACTICS: THE WAR OF THE LIONS
}

\author{
*Jauza Munirah \\ **Amrin Saragih \\ **Elisa Betty Manullang
}

\begin{abstract}
Munirah, Jauza. 2132220020. Psychological Approach to the Characters of ELiterature Final Fantasy Tactics: The War of the Lions. A Thesis. Faculty of Languages and Arts, State University of Medan. 2017.
\end{abstract}

The aim of this study is to investigate the structures of personalities, the driving forces behind behaviors, the interweaving roles of the characters in a videogame titled Final Fantasy Tactics: The War of the Lions and how those roles affect the overall literary works. The type of this research is qualitative. The .iso, script as well as the documentation videos of Final Fantasy Tactics: The War of the Lions are the sources of the data. The data are the utterances and actions which conveys the characters' perceptions in a particular physical and social environments, their needs, wishes, intentions, memories of past events and their imagining about future, their ways to overcome inferiority, the future they envision, their goals and expectations. The writer finds that the seemingly opposite characters actually share similar goals: to fight the imbalances, particularly the social disparity between noble and commoner and to make the world a better place. Both characters start to differ because of their differences in backgrounds which lead one to seek power while the other one abandoned power. Each characters have their own assigned roles based on the application of Jung's archetypes, and they share similar roles. But, while most a character's roles changes to the shadow sides (the negative sides) because of the situations that occured, the other character retains the positive qualities of the archetypes. Both characters become the antithesis of each others and their interweaving roles lead to a deeper and complex interpersonal conflicts, a more interesting story, as well as a great emotional impacts.

Keywords: Archetypes, Characters, Characterizations, Driving Forces, Electronic Literature, Final Fantasy, Literary Works, Psychological Approach, Structure of Personality, Videogame

*Graduate Status

** Lecturer Status 


\section{INTRODUCTION}

\section{The Background of the Study}

As our civilizations develop and we reach the era of digital, we are able to witness many aspects of our civilization change. One of the many changes we can see is in the field of literature. Generally, there are three forms of literature that are considered as literary works. They are prose, poetry, and drama. But, in line with what Culler (2007) says, “...one thing we know about literature is that it always seeks to outplay itself in acts of reinvention," the boundaries of literature have widened up and literature continues to evolve. Now, the advancement of technology along with human creativity have made it possible for the emergence of a new form of literature - the electronic literature, and a new medium for literary works, such as videogame.

Videogames are the merging of various art forms, like literary writings and visual arts. In 2005, though, Ebert - a notable film critic, stirred the world in controversy when he implied that videogames can never be art. According to Ebert (2005), "books and films are better mediums and better uses of time. But how can I say that when I admit I am unfamiliar with videogames?” Ebert (2005) also says, “...that a game can aspire to artistic importance as a visual experience, I accept. But for most gamers, video games represent a loss of precious hours to make ourselves more cultured, civilized and empathetic." 
Although it's true like Ebert says, that game is a visual experience, games continue to develop. Some games nowadays put a heavy emphasis on language (texts) as the main aspect of literature as well as other literary aspects that will makes us more cultured, civilized and empathetic. To play those games is certainly not "...a loss of precious hours" as Ebert (2005) implies. Because throughout the powerful literary qualities of both games, the player will experience and learned something.

The literary qualities of videogames have great values. Sadly, they are often ignored. This results in lots of potentially great stories and characters to be wasted. By analyzing a game, the writer hopes to bring the literary aspects of games into awareness. Out of some literary qualities, the writer will put the emphasis on the characters and characterization because characters and characterization are very important in literary works.

Final Fantasy Tactics: The War of the Lions (FFT: TWotL) was chosen because it features complex characters. The complex characters will highlight one of the purposes of literature, as Todorov (1973) defines it, is the writing that "allows us to better understand the human condition." This game's layered storylines cover various themes that reflect the society and the human's conditions. Since literature has to tell about human, morality, issues, and everything humanity faces, this game is also a good representation of human's complexities. Two of the game's heroes, Delita and Ramza, are on the surface in contrast with each other. They can easily categorized into a protagonist and an antagonist. But, there are more to the characters than only 
black and white. To fully understand the characters and their acts, we have to know their structures of personalities, motives, and everything that shapes them as the person they are. And it is when the psychology of literature approach is needed. Because literary works always intertwines with humanity, the knowledge of psychology is needed to have a better understanding of the author or character in literary works, as Endraswara (2003) explains, "psychology of literature look at the characterization of characters based on psychological principles or at the author ideas, thoughts and feelings when he created his works."

The characters will be understood better through observing their characterizations which manifest in form of actions and words. By observing Delita and Ramza's actions and words in Final Fantasy Tactics: The War of the Lions (FFT: TwotL), we will know their structures of personalities, the driving forces behind their behaviors and to what archetypes they fell to. We will then get a better understanding of their personalities, motives, roles, and how those qualities affect the overall literary works.

\section{REVIEW OF LITERATURE}

According to Krystal (2014), literature or lit(t)eratura refers to any writing formed with letters. In its broadest sense, literature are written works that are published. Later though, the definition of literature was narrowed to only written works that have a sense of literary and tends to be in favor of the fictions rather than the nonfictions. In this sense, literature are the literary writings that can be considered as a work of art such as novel, poetry, and 
drama. But as we reach the era of digital, civilization's use of technology are vast, resulting in the emergence of new literary form: electronic literature, as Bell et al (2014) states, "the mainstream media heralds a digital age in which we read literature differently, i.e. on screen." Hayles (2008) says, "Just as the history of print literature is deeply bound up with the evolution of book technology as it built on wave after wave of technical innovations, the history of electronic literature is entwined with the evolution of digital computers". Wardrip-Fruin (2013) explains that electronic literature refers to "work with important literary aspects that requires the use of digital computation."

Nowadays, there are lots of videogames which incorporate important literary aspects which are called literary games. Literary games are games with narratives that have the quality of literary writings which affect readers, evoking emotions and give impacts because "a fundamental aspect of storytelling is the emotions, that the story evokes in its audience" (Lugmayr, et al: 2017). Ensslin (2014) states that literary games combine ludic (from Latin ludus: game or play) and literary (from Latin litterae: a piece of writing).

Just like other literary works, literary games also have characters which reflect the real humans. Thus psychological approach is needed to have a better understanding of characters in literary works. Lewin-a pioneer of modern social psychology, coined the term life space to explain the structure of personality. According to Lewin (1996), "a person's life space might include for example, his perception of himself in physical and social environment, his needs, wishes and intentions, his memories of particular past events and his 
imagining about future ones." Adler-the founder of individual psychology school of thoughts, believes that human behavior is guided by what is called as fictional final goals which represents our ideas of what is possible based on our interpretation of the world. According to Adler (1930), "human being is motivated by the urge to overcome the feeling of inferiority and to become superior". Human beings' primary drive is to become better - the goals they set themselves are expressions of ideal states, expressions that help in dealing with the environment. Thus, behavior is determined by the future we envision-by goals and expectation's. (Introduction to Theories of Personality by Calvin S.Hall and Gardner Lindzey)

Besides the characters' structures of personalities and driving forces behind behaviors, characters roles based on Jung's archetypes will be decided. There are 12 archetypes commonly used in literary works characterizations: The Innocent, The Orphan, The Hero/The Warrior, The Caregiver, The Seeker, The Lover, The Destroyer/The Rebel, The Creator, The Ruler, The Magician, The Sage, The Fool/The Jester. Each archetypes have their own set of qualities and sides, the shadow (negative sides) and the light (the positive sides).

\section{RESEARCH METHODOLOGY}

\section{Methodology}

This research was conducted by applying the descriptive qualitative method. According to Molleong (2007), "qualitative is a method which is aimed to understand the phenomenon of what the subject experience about, such as behavior, perception, motivation, and action". In line with this 
description, this study was intended to understand the two main heroes of Final Fantasy Tactics: The War of the Lions game, Delita and Ramza.

\section{Data Analysis}

To analyze the data, the specific utterances regarding Delita and Ramza characters were decided. The characters' structures of personalities were then infered based on the indicators set by Lewin's life space theory. After that, the driving forces behind the characters' behaviors were infered based on Adler's fictional final goal theory. In the end, the characters' Jungian archetypes were derived. The characters' roles in the story were then determined and their intertwined roles as antihero and hero (shadow and light) were examined to describe how their characterization affects the literary works Final Fantasy Tactics: The War of the Lions.

\section{DATA ANALYSIS AND RESEARCH FINDINGS}

Data Analysis

\section{The Structures of Personalities}

a) Delita

\begin{tabular}{|l|l|l|l|l|l|}
\hline $\begin{array}{c}\text { Perception of } \\
\text { Himself in } \\
\text { Physical/Social } \\
\text { Environment }\end{array}$ & Needs & Wishes & Intentions & $\begin{array}{l}\text { Memories } \\
\text { of Past }\end{array}$ & $\begin{array}{l}\text { Imagining } \\
\text { about } \\
\text { Future }\end{array}$ \\
\hline $\begin{array}{l}\text { Feel powerless } \\
\text { because of his } \\
\text { commoner } \\
\text { status. }\end{array}$ & $\begin{array}{l}\text { To become } \\
\text { stronger by } \\
\text { training and } \\
\text { rely on } \\
\text { himself. }\end{array}$ & $\begin{array}{l}\text { To make } \\
\text { Ivalice a } \\
\text { better } \\
\text { kingdom. }\end{array}$ & $\begin{array}{l}\text { Stopping } \\
\text { the villains } \\
\text { and exact } \\
\text { vengeance. }\end{array}$ & $\begin{array}{l}\text { Witnessing } \\
\text { cruel } \\
\text { treatments } \\
\text { to the } \\
\text { commoner. }\end{array}$ & $\begin{array}{l}\text { A better } \\
\text { Ivalice. }\end{array}$ \\
\hline
\end{tabular}


b) Ramza

\begin{tabular}{|l|l|l|l|l|l|}
\hline $\begin{array}{l}\text { Perception of } \\
\text { Himself in } \\
\text { Physical/Social } \\
\text { Environment }\end{array}$ & Needs & Wishes & Intentions & $\begin{array}{l}\text { Memories } \\
\text { of Past }\end{array}$ & $\begin{array}{l}\text { Imagining } \\
\text { about } \\
\text { Future }\end{array}$ \\
\hline $\begin{array}{l}\text { Feel powerless } \\
\text { despite his } \\
\text { status as a } \\
\text { noble, he feels } \\
\text { like he does not } \\
\text { belong to the } \\
\text { nobility and } \\
\text { rebelled against } \\
\text { them. }\end{array}$ & $\begin{array}{l}\text { To become } \\
\text { stronger by } \\
\text { having } \\
\text { allies. }\end{array}$ & $\begin{array}{l}\text { To make } \\
\text { Ivalice a } \\
\text { better } \\
\text { kingdom. }\end{array}$ & $\begin{array}{l}\text { Stopping } \\
\text { the villains } \\
\text { to live up to } \\
\text { his virtue as } \\
\text { a knight. }\end{array}$ & $\begin{array}{l}\text { Witnessing } \\
\text { cruel } \\
\text { treatments } \\
\text { to the } \\
\text { commoner. }\end{array}$ & $\begin{array}{l}\text { A better } \\
\text { Ivalice. }\end{array}$ \\
\hline
\end{tabular}

\section{The Driving Forces behind Behaviors}

a) Delita

After various conditions that happened to him, it is infered that Delita's main motive is mostly the power. This is rooted from Delita's experiences with his environment, in which he saw that the weak ones were exploited. His fear of other exploitations then drives Delita to seek power. When he got the power, he plans to realize a better Ivalice.

b) Ramza

From his conditions, it is seen that Ramza seeks the truth and answers regarding the condition of the world which he lives in. He values alliance and is also a pacifist person who refrains from fighting whenever possible. Ramza believes that as a knight and a member of the House Beoulve, it is his duty to stay on the innocent people's side and save them from the power-hungry's agendas. 


\section{Characters' Roles and Effect and Their Effect to Literary Works}

\begin{tabular}{|l|l|c|l|c|c|}
\hline No & \multicolumn{1}{|c|}{ Archetypes } & Delita & Sides & Ramza & Sides \\
\hline 1. & The Innocent & & & $\sqrt{ }$ & Light \\
\hline 2. & The Orphan & $\sqrt{ }$ & Shadow & & \\
\hline 3. & The Hero/Warrior & $\sqrt{ }$ & Shadow & $\sqrt{ }$ & Light \\
\hline 4. & The Seeker & $\sqrt{ }$ & Shadow & $\sqrt{ }$ & Light \\
\hline 5. & The Lover & $\sqrt{ }$ & Shadow & $\sqrt{ }$ & Light \\
\hline 6. & The Destroyer/Rebel & $\sqrt{ }$ & Shadow & $\sqrt{ }$ & Light \\
\hline 7. & The Caregiver & $\sqrt{ }$ & Shadow & $\sqrt{ }$ & Light \\
\hline 8. & The Creator & $\sqrt{ }$ & Shadow & & \\
\hline 9. & The Ruler & $\sqrt{ }$ & Shadow & & \\
\hline 10. & The Magician & $\sqrt{ }$ & Shadow & $\sqrt{ }$ & Light \\
\hline 11. & The Sage & $\sqrt{ }$ & Shadow & $\sqrt{ }$ & Light \\
\hline 12. & The Fool & & & & \\
\hline
\end{tabular}

The roles assigned to the Final Fantasy Tactics: The War of the Lions was analyzed by applying Jung's twelve archetypes. In Final Fantasy Tactics: The War of the Lions, it is commonly seen that Ramza is a protagonist while Delita is an antagonist. But based on their structures of personalities and the driving forces behind their behaviours, it is not entirely true to regard Delita as a pure antagonist. Rather, Delita and Ramza are both the heroes of the Final Fantasy Tactics: the War of the Lions game. But as the game's story goes on, both the heroes path started to differs. Ramza stay on the virtuous path while Delita stray to the dark side (the shadow side). Delita then develop into an antihero, but not a true villain. This complex characterizations of both character makes the literary works more interesting to follow, as we started to question the characters. The interpersonal relationship between the characters in the game also becomes more complex as both heroes become the antithesis of each other. We learned a lot about human's conditions and the characters becomes more than just a shallow characters. 


\section{CONCLUSION, SUGGESTIONS, AND IMPLICATIONS}

\section{Conclusions}

After the data from Final Fantasy Tactics: The War of the Lions were analyzed, the conclusions are drawn as the following:

1. Based on their structures of personalities, both characters have similar goals; to fight the imbalances, particularly the social disparities between the nobles and the commoners and to make the world a better place.

2. Based on their driving forces behind behaviors, both characters started to differs because of their different social backgrounds. Delita who is a commoner was driven by his cravings for power and thus seeks to be powerful. While Ramza, despite already hold a noble status, started to question whether it's really matters. Later he abandoned his noble status and concludes that instead of status, it is our deeds that makes us a true noble.

3. Each characters have their own assigned roles based on the application of Jung's archetypes. Both characters shares similar roles, but while most of Delita's roles changes to the shadow sides (the dark or negative sides), Ramza retains the pure or positive qualities of the roles he was assigned to. Both characters' roles are interweaving as they become the antithesis of each others although both of them still hold the same goals. The interweaving roles leads to deeper and complex interpersonal conflicts and a more interesting story. The complexity between the characters will also give a better impacts for the audiences, specifically the emotional impacts. 


\section{Suggestions}

In relation to the conclusions, suggestions are staged as the following:

1. When creating a character, it is suggested to make the personality more structured. It can be by applying Lewin's theory of life space or other psychological theories, since psychology and literature are related.

2. To refrain from creating a shallow character, the driving forces behind behaviors are needed. The driving forces must be derived from the character's structure of personality, backgrounds, goals, memories, and expectations so that the character will not feel out of character.

3. Characterizations is very important. To add richness to the story and characters, it is better to assign the characters to specific roles. But to refrain from being monotonous, experimenting with combined roles is suggested. To refrain from creating two-dimensional characters, adding the shadow (dark/negative) roles must also be taken into account.

\section{Implications}

The implications of this study are as the following.

1. The object for this literary analysis is a game called Final Fantasy Tactics: The War of the Lions. Although it is unusual for games to be treated as an object of literary study, some games does fit the criterias' of literary works.

2. Games can be a great medium of storytelling, and Final Fantasy Tactics: The War of the Lions shows that. The characterization is great and befits a literary works. So in the future, hopefully every literary mediums (traditionals and electronics) can co-exist together, expanding the horizon of literary works. 


\section{REFERENCES}

Adler J, Alfred. (1930). The Science of Living. London: Lowe \& Brydone Printers

Ansbacher, Heinz L and Ansbacher Rowena L. (1956). The Individual Psychology of Alfred Adler. New York: Basic Books

Bell, Alice, Ensslin A. and Rustad H.K. (2014). Analyzing Digital Fiction. New York: Routledge

Calvin, S. H. and Lindzey, G. (1970). Theories of Personality. New York: Willey

Ebert, Roger. (2005, November 2007). Why Did the Chicken Cross the Genders. Retrieved from http://www.rogerebert.com/answer-man/why-did-thechicken-cross-the-genders on August, 20th 2017

Endraswara, Suwardi. (2003). Metodologi Penelitian Sastra: Epistemologi, Model, Teori dan Aplikasi. Yogyakarta: Pustaka Widyatama

Ensslin, Astrid. (2014). Literary Gaming. Cambridge: MIT Press

Golden, Carl. (n.d) Essay on The Twelve Common Archetypes. Retrieved from http://www.soulcraft.co/essays/the_12_common_archetypes.html on June, 6th 2017

Hayles, N. Katherine. (2008). Electronic Literature: New Horizons for the Literary. Indiana: University of Notre Dame.

Jonas, J.J. (n.d.). The Twelve Archetypes. Retrieved on July 15, 2017. http://www.uiltexas.org/files/capitalconference/Twelve_Character_Arc hetypes.pdf

Jung, Carl translated by Hull, R.F.C. (1969). The Collected Works of Carl G. Jung Vol 9 Part 1 Archetypes and the Collective Unconcious. New York: Princeton University Press

Krystal, Arthur. (2014). What is Literature. Harper's Magazine March Issue. Retrieved from http://harpers.org/archive/2014/03/what-is-literature/1 on on January 25, 2017.

Lewin, Kurt translated by Heider Fritz and Heider Grace M. (1936). Principles of Topological Psychology. New York: McGraw Hill Book Company 
Lugmayr, A., Sutinen, E., Suhonen, J. et al. (2017). Serious Storytelling - A First Definition and Review. Multimedia Tools and Applications, 76 (14)

Moleong, Lexy J. (2007). Metodologi Penelitian Kualitatif, Bandung: PT Remaja Rosdakarya Offset

Mukherjee, Souvik. (2015). Video Games and Storytelling: Reading Games and Playing Books. New York: Palgrave Macmillan.

Ostenson, Jonathan. (2013). Exploring the Boundaries Narrative: Video Games in the English Classroom. English Journal, 102 (6)

Todorov, Tzvetan. (1973). The Notion of Literature. New Literary History, 5 (1)

Wardrip-Fruin, Noah. (2013). Reading Digital Literature: Surface, Data, Interaction and Expressive Processing (in "A Companion to Digital Literary Studies" edited by Siemens, Ray and Schreibman, Susan). Oxford: Blackwell Publishing.

Wardrip-Fruin, Noah. (2009). Expressive Processing: Digital Fictions, Computer Games, and Software Studies. London: The MIT Press. 